\title{
Slender-billed Curlew (Numenius tenuirostris) in the Czech Republic: the historical occurrence of this species in Bohemia and its return on the checklist
}

Jiř́ J. Hudeček

\begin{abstract}
Slender-billed Curlew (Numenius tenuirostris) in the Czech Republic: the historical occurrence of this species in Bohemia and its return on the checklist. - Acta Mus. Siles. Sci. Natur. 65: 71-73, 2016.

Abstract: The Slender-billed Curlew (Numenius tenuirostris) is a higly endangered, almost extinct shorebird species in Europe. This paper describes little-known evidence about its occurrence in the Bohemian territory, which could help to get this species back on the checklist of birds in the Czech Republic.
\end{abstract}

Key words: Slender-billed Curlew (Numenius tenuirostris), occurrence, Jiř́i Janda, Bohemia, Czech Republic, historical ornithology

\section{Introduction}

The Slender-billed Curlew, a higly endangered species very common in Europe in the 19 th century, but rare in the 20 th century, used to nest in the vicinity of Tomsk in Russian Siberia between 1909 and 1925. It could be seen flying more often in southern Europe, in the Middle East and in northern Africa (Gretton et al. 2002; Cleeves et al. 2008; Buchanan et al. 2010; Corso et al. 2014; Kirwan et al. 2015). The causes if its vanishing might have been environmental changes, hunting and other factors (Vangeluwe et al. 1998; Have \& Gallo-Orsi 2001; Donald et al. 2010; Brown et al. 2014; BirdLife International 2015). Today there might be fifty individuals. This species was described in 1817 by L. J. P. Vieillot, based on findings from Egypt in 1798 (typus in NHM Paris, France, Oehler 1948; Voisin \& Voisin 2012; Jansen 2015). In Europe it was seen for the first time in Italy and Greece (Bonaparte 1833; Anonymus 1842; Schlegel 1844; Naumann 1851) and in Germany in the first half of the 19 th century (Bauše 1899; Fritsch 1870).

\section{The Slender-billed Curlew in the Czech Republic and in central Europe}

The historical occurrence of the Slender-billed Curlew in the Czech Republic was presented by Hudec \& Černý (1977), Hudec et al. (1995), Kren (2000) and Hudec \& Št’astný (2005). Anděra (2003) claimed that this occurrence cannot be backed up any trustworthy evidence and Mlíkovský (2004) questioned it all. The Czech Rarities Committee has crossed out this species from the birds checklist without giving any sources, saying: confusion, mistakes in localization, insufficient description (to 15.XII.2011, Anonymus s. d. a, b; 2013; Vavř́k 2015). Because the possibility of repeated occurrences in central Europe is nowadays low (last time it was seen in Hungary in 2001, Oláh \& Pigniczki 2010), the historical reports about its occurrence in individual countries are carefully kept (Renner et al. 1995; Gallo-Orsi et al. 2001; Barthel \& Helbig 2005; Koválik et al. 2010; Stawarczyk in litt.). If it is not possible to trace back evidence of a literary source, there is no reason to ceross that item out. The absence of evidence after World War II was mainly caused by uncontrolled perishing of historic ornithological collections and connected writings (Crockford 2009; about their extent, see Štěpánek 1956). Elimination of sources (literature) and rewriting of facts might destroy historic ornithology in Czech countries. It is nice to see that in the world avibase, this species is still to be found in Czech Republic (Lepage 2015). 


\section{The occurrence in Bohemia}

Factually, J. Janda's report is totally unknown. He gave it to K. Hudec for the needs of AERC (Hudeček in Hudec et al. 1995).

Janda (1927: 297) cleary said that the Slender-billed Curlew had been seen a few times in Bohemia and Moravia, he hadn't excluded its next occurrence and that was why he was enclosing its description. Following that Janda (1913: 505; 1930: 441) cleary wrote in a footnote: "A few years ago this report was sent to me from Bohemia. Unfortunately I do not have it on me". This might have been between 1902 and 1913 (Janda 1902: not evidence). J. Janda also justified the spatial and time incompleteness of the data. Similary incomplete reports are accepted in geographical localization in biology and in European literature (see Anonymus s. d. c, specimen in collection by C. L. Brehm, Thüringen, Germany, Rost \& Grimm 2004).

Jiří Janda (1865-1938) was a accidental school teacher, a founding member of the Czech Ornithology Society and an important Czech zoologist and ornithologist (Štorkán 1934; Musílek 1938; Gebhardt 1964; Hudec 1999; Heráňová 2013; 2014).

Acknowledgements: Author would like to thank to P. Faksová, A. Klocová, L. Kratochvílová and prof. Dr. T. Stawarczyk for helping me with my work, and to M. Indráková for translation. Article is dedicated to the 150 th birth anniversary of prof. Jiř́i Janda.

\section{References}

Anděra M. (2003): Fauna. Encyklopedie naší př́rody. Nakl. Libri, Praha.

Anonymus (1842): The Encyclopaedia Britannica or Dictionary of Arts, Sciences and General literature. Seventh edition, Vol. XVI. A. \& Ch. Black, Edinburgh.

- (s. d., a): Koliha tenkozobá - Numenius tenuirostris. Available from: fkcso.sweb.cz/numten-h.htm

- (s. d., b): Koliha tenkozobá - Numenius tenuirostris. Available from: fkcso.sweb.cz/numten. htm

- (s. d., c): Locus typicus. Available from: www.thefreedictionary.com/Locus+typicus

- (2013): Faunistická komise ČSO. Aktuality. Available from: fkcso.cz/body2013.html

Barthel P.H. \& Helbig A.J. (2005): Artenliste der Vögel Deutschlands. - Limicola 19(2): 89-111.

Bauše B. (1899): Koliha, Numenius. Ottův slovník naučný, 14. díl: 552. Vyd. a nakl. J. Otto, Praha.

BirdLife International (2015): Species: Slender-billed Curlew, Numenius tenuirostris. Available from: http://www.birdlife.org (on 21.12.2015).

Bonaparte C.L. (1833): Bemerkungen über die Angabe von Cuviers Thierreich. - Isis von Oken 11: 10411120.

Brown D., Crockford N. \& Sheldon R. (2014): Drivers of population change and conservation priorites for the Numenini populations of the world. In: Convention on migratory species, Quito, Ecuador, 4. -9. November 2014: 1-75.

Buchanan G., Crockford N. \& Gretton A. (2010): The Slender-billed Curlew Numenius tenuirostris in Africa. - African Bird Club Bull. 17(2): 202-206.

Cleeves T., Crockford N. \& Köhler P. (2008): Die grösste feldornithologische Herausforderung Europas: Die suche nach der Dünnschnabelbrachvogel. - Der Falke 55: 419-428.

Corso A., Jansen J. \& Kókay S. (2014): A review of the identification criteria and variability of the Slenderbilled Curlew. - Brit. Birds 107: 339-370.

Crockford N. (2009): Can you help find the Slender-billed Curlew ? - Wader Study Group Bull. 116(1): 6264.

Donald P., Collar N., Marsden S. \& Pain S. (2010): Facing extinction: The Worlds rarest birds and the race to save them. 2nd edition. T. \& D. Poyser, London.

Fritsch A. (1870): Naturgeschichte der Vögel Europas. Tempsky, Prag.

Gallo-Orsi U. \& Boere G.C. (2001): The Slender-billed Curlew, Numenius tenuirostris: Threats and Conserva-tion. - Acta Ornithol. 36(1): 73-77.

Gebhardt L. (1964): Die Ornithologen Mitteleuropas. Ein Nachschlagenwerk. Brühlscher Verlag, Giessen.

Gretton A., Yurlov A.K. \& Boere G.C. (2002): Where does the Slender-billed Curlew nest, and what future does in have? - Brit. Birds 95: 334-344.

Have van der T. M., Gallo-Orsi U. (2001): Population trend of the Slender-billed Curlew Numenius tenuirostris 1850-2000. - Wader Study Group Bull. 96: 24 (abstract).

Heráňová H. (2013): Biography and bibliography of prof. Jiří Janda (1865-1938). - Gazella 40: 99-113. 
- (2014): Jiří Janda, polozapomenutý vědec a publicista. - Živa 62(1): IV-V.

Hudec K. (1999): Ornitologové České republiky. Vyd. Muz. Komen. v Přerově a Asociace čes. a morav. muzeí ve spolupráci s Mor. ornitol. spolkem, Přrerov.

Hudec K. \& Černý W. (eds) (1977): Fauna ČSSR, sv. 21. Ptáci-Aves. Díl II. Academia, Praha.

Hudec K. \& Št’astný K. (eds) (2005): Fauna ČR, sv. 29/2. Ptáci-Aves. Díl II/2. 2., přeprac. a doplněné vyd. Academia, Praha.

Hudec K., Chytil J., Št’astný K. \& Bejček V. (1995): The birds of the Czech Republic. - Sylvia 31: 97-149.

Janda J. (1902): Atlas ptactva středoevropského se zvláštním zřetelem k druhům domácím. Nakl. I. L. Kober, Praha.

- (1913): Velký illustrovaný př́írodopis všech trři říšíi. I. Ssavci-Ptáci. Nákl. Zem. ústřed. spolku Jednot učit. V Král. čes. v Komisi Ústřed. nakl. a knihkup. učit. Českoslovanského, Praha.

- (1927): Ptáci. Díl III., sv. 2. Život zvířat. Napsal A. Brehm. Tinamy, Kurovití, Jeřábovití, Kulíkovití. Nakl. J. Hokr, Praha.

- (1930): Velký ilustrovaný př́rodopis všech tř́ ř́íší. I. Ssavci-Ptáci. 2., přeprac. a doplněné vyd. Ústř̌ed. nakl. a knihkup. učit. Českoslovanského, Praha.

Jansen J.J.F.J. (2015): The Birds collection of the Museum National d'Histoire Naturelle, Paris, France: the first years (1793-1825). - Journal of Nat. Mus. (Prague), Nat. Hist. Ser. 184(5): 81-111.

Kirwan G., Porter R. \& Scott D. (2015): Chronicle of an extinction? A review of Slender-billed Curlew records in the Middle East. - Brit. Birds 108: 669-682.

Koválik P., Topercer J., Karaska D., Danko Š. \& Šrank V. (2010): A checklist of birds of Slovakia to April 7, 2010. - Tichodroma 22: 97-108.

Kren J. (2000): Birds of the Czech Republic. 1st ed. Christopher Helm, London.

Lepage D. (2015): Avibase-the world bird database. Czech Republic. Downloaded from: avibase.bsc-eoc.org/ checklist.jsp?region=CZalist=clements.

Mlíkovský J. (2004): Remarks on some records of the Slender-billed Curlew (Numenius tenuirostris). Sylvia, 40: 125-130.

Musílek J. (1938): In memoriam prof. Jiř́ího Jandy. - Sylvia 3(3): 45-47.

Naumann J.F. (1851): Das Vorkommen seltener europäischer Vögel in unsern Anhalt. - Naumannia 1: 1-23.

Oehser P.H. (1948): Louis Jean Pierre Vieillot (1748-1831). - Auk 65(4): 568-576.

Oláh J. \& Pigniczki C. (2010): The first XXIst century record of Slender-billed Curlew in Hungary. - Aquila 116-117: 49-53.

Ranner A., Laber J. \& Berg H.-M. (1995): Nachweise seltener und bemerkenswerten Vogelarten in Österreich 1980-1990. - Egretta 38: 59-98.

Rost F. \& Grimm H. (2004): Kommentierte Artenliste der Vögel Thüringens. - Anz. Ver. Thüring. Ornithol., Sonderheft 5: 3-78.

Schlegel H. (1844): Revue critique des oiseaux d'Europe. A. Arnz \& Comp., Leiden.

Štěpánek O. (1956): Ornithologické sběratelství a sbírky v Čechách a na Moravě. - Sbor. předn. I. celostát. konf. Čsl. ornithol. společ v Praze, v ř́ijnu 1956, pp. 73-76.

Štorkán J. (1934): Janda Jiří. - Ottův slovník naučný nové doby. Dodatky k velikému Ottovu slov. nauč., 3 (1): 94. Nakl. J. Otto, Praha.

Vangeluwe D., Handrinos G. \& Bulteau V. (1998): Le point sur le Courlins a bes Gréce Numenius tenuirostris. Oúl'observer, coment l'identifer ? - Ornithos 5: 22-35.

Vavřík M. \& Fk ČSO (2015): Checklist of birds of the Czech Republic. Downloaded for: fkcso.cz/cz-list.htm

Voisin C. \& Voisin J.- F. (2012): List of type specimens of birds in the collections of the Museum national'd Histoire Naturelle (Paris, France). 23. Charadriiformes (Part 2: Rostratulidae, Haematopodidae, Charadriidae, Scolopacidae, Recurvirostridae, Glareolidae). - Journal of Nat. Mus. (Prague), Nat. Hist. Ser. 181(5): 27-58.

\section{Koliha tenkozobá (Numenius tenuirostris) na území České republiky: historický výskyt v Čechách a návrat druhu na checklist}

Koliha tenkozobá (Numenius tenuirostris) je kriticky ohrožený, téměř vymřelý druh bahňáka v Evropě. Je popsán málo známý důkaz výskytu na území Čech, zakládající návrat vyškrtnutého druhu zpět na seznam druhů ptáků České republiky.

Author's address: Jiří J. Hudeček, Hraniční 151 \& 230, CZ-742 83 Klimkovice, Czech Republic. E-mail: waldrapp@seznam.cz 